\title{
INISIASI KEPALA DESA DALAM PEMBANGUNAN SUMBER DAYA MANUSIA GUNA MEMENUHI PELUANG KERJA DI KOTA BATU
}

\author{
Lorensius Helu Ngara, Agung Suprojo \\ Program Studi Administrasi Publik, Fakultas Ilmu Sosial dan Ilmu Politik, \\ Universitas Tribhuwana Tunggadewi Malang \\ e-mail: lorensiushelungara12@gmail.com
}

\begin{abstract}
Abstrak: Inisiasi kepala desa sebagai suatu proses dan berinsiatif yang sangat penting, memiliki motor penggerak mencapai tujuan yang efektif dan efisien. Secara umum berhasil atau gagalnya suatu organisasi tergantung pada inisiasi kepala desa yang diterapkan oleh pimpinan pada semua tingkat. Dalam penelitian ini digunakan metode penelitian kualitatif. Pengumpulan data melalui teknik observasi, pengamatan, dan dokumentasi, instrumen penelitian yakni peneliti sendiri, pedoman wawancara dan catatan lapangan. Teknik sampling meliputi purposifel sampling, keabsahan data menggunakan teknik triangulasi. Pembangunan sumber daya manusia di Desa Mojorejo Kecamatan Junrejo Kota Batu sudah menunjukkan arah perkembangan yang positif dan adanya kemajuan, dengan adanya pembangunan sumber daya manusia diharapkan dapat meningkatkan kesejahteraan masyarakat. FaktorpendukungSikap masyarakat yang selalu menerima secara positif setiap program yang diberikan oleh Pemerintah Desa. Sedangkan faktor penghambat Rendahnya kualitas Sumber Daya Manusia (SDM) dan kurang memadainya alat sarana dan prasarana pendidikan yang masih kurang dan adanya Kerja sama yang akan dijalin di fokuskan dalam bidang pendidikan, penelitian, dan pengembangan serta pengabdian kepada masyarakat.
\end{abstract}

Kata Kunci : Pembangunan; Sumber Daya Manusia; Peluang Kerja

Abstract: The initiation of the village head as a process and an initiative which is very important since it has a driving force to achieve effective and efficient goals. In general, the success or failure of an organization depends on the initiation of the village head which is implemented by leaders at all levels. This study is a qualitative research with the data collection was through observation and documentation. The research instruments were the researchers themselves, interview guides and field notes. The sampling techniques includeda purposive sampling with the validity of the data using triangulation techniques. The development of human resources in Mojorejo Village, Junrejo District, Batu has shown a positive direction, with the human resource development expected to improve the welfare of the community. The supporting factors were the community attitudes that always positive to every program given by the Village Government. While the inhibiting factors were the low quality of Human Resources (HR) and inadequate educational facilities and infrastructure and the lack ofcooperation that focused on education, research, development and community service.

Keywords : Development; Human Resources; Job Opportunities

\section{PENDAHULUAN}

Pembangunan merupakan suatu proses mutlak yang dilakukan oleh suatu bangsa dalam meningkatkan taraf hidup dan kesejahteraan seluruh bangsa tersebut. maka di Indonesia yang salah satunya sebagai negara yang berkembang masih mengalami ketertinggalan dibandingkan dengan negara-negara industri maju dalam pembagunan ekonominya yang masih mengharuskan pemerintah untuk mengambil peranan sebagai roda penggerak pembagunan ekonomi nasional. 
Pembangunan ekonomi di negara berkembang memiliki kesamaan dengan negara-negara maju yangmembutuhkan beberapa faktor yang menjadi modal pembangunan, sebagai berikut; sumber daya manusia, sumber daya alam, pembentukan modal, dan tingkat teknologi.

Kenyataannya di negara-negara berkembang faktor dari pertambahan populassi penduduk menjadi faktor pertumbuhan ekonomi. Pertambahan jumlah penduduk yang bertambah dari waktu ke waktu dapat menjadi pendorong maupun penghambat kepada perkembangan ekonomi. Apabila lajutumbuhan sama dengan tingkat pertambahan penduduk maka akan terjadi stagnasi ekonomi., Menurut syamsi (yuswar zainul basri dan mulyadi subri, 3003:15) pembangunan adalah proses perubahan sistem yang dirancanakan kearah perbaikan yang orientasinya pada modernisasi pembangunan dan kemajuan sosial ekonomi.

Salah satu faktor penting yang menentukan kemakmuran suatu rakyat adalah tingkat pendapatannya. Pendapatan masyarakat mencapai maksimum dengan tingkat penggunaan tenaga kerja penuh dapat diwujudkan. Pengangguran mengurangi pendapatan masyarakat, dan mengurangi tingkat kemakmuran yang mereka capai. Ditinjau dari sudut pandang individu, pengangguran menimbulkan berbagai masalah ekonomi dan sosial kepada yang mengalaminya. ketiadaan pendapatan menyebabkan para penganggur harus mengurangi pengeluaran ekonomisnya.

Di samping itu dapat mengganggu taraf kesehatan keluarga. Pengangguran yang berkepanjangan menimbulkan efek psikologi yang burukdari pengangguran dan keluarganya. Apabila keadaan pengangguran di suatu negara terburuk, kekacauan politik dan sosial selalu berlaku dan menimbulkan efek yang buruk kepada kesejahteraan rakyatnya dan prospek pembangunan ekonomi dalam jangka panjang. Nyatalah bawasanya masalah pengangguran adalah masalah yang sangat buruk efeknya kepada perekonomian dan masyarakat, oleh karena secara terus menerus uasaha-usaha dilakukan untuk mengatasinya.

Menurut Siangian (2008:138) pembangunanan merupakan suatu rangkaian usaha untuk mewujudkan pertumbuhan dan perubahan secara terencana serta sadar, yang ditempuh oleh suatu negara menuju modernitas dalam rangka pembinaan bangsa. Pembangunan merupakan salah satu hal yang sangat penting di dalam kehidupan suatu negara, pembangunan dapat menentukan berhasil atau tidaknya suatu negara tersebut dalam memajukan kehidupan ekonomi bangsa, atau juga dapat dikatakan bahwa pembangunan merupakan tujuan utama didirikanya suatu negara guna untuk mensejahterakan kehidupan masyarakatnya.

Namun demikian, seperti pada paparan di atas, bahwa salah satu faktor yang menjadi perhatian penting adalah kualitas sumber daya manusianya. Hasil paparan penelitian Rohman, A. (2018) menunjukkan bahwa tingkat pendidikan, kualitas sumber daya manusia baik itu pemimpin maupun masyarakatnya sangat mempengaruhi penyelenggaraan pemerintahan desa. Sehingga hal ini menjadi menarik untuk diteliti untuk mengethaui inisiasi Kepala Desa sebagai pemimpin dalam pembangunan sumber daya manusia guna memenuhi peluang kerja.

\section{METODE PENELITIAN}

Metode penelitian adalah cara yang digunakan oleh penelitian untuk mendapatkan data dan informasi mengenai berbagai hal yang berkaitan dengan masalah yang diteliti. Istilah metode, berasal dari kata methodos (Yunani) yang berarti cara atau jalan. Menyangkut dengan upaya ilmiah, metode dihubungkan dengan cara kerja, yaitu cara kerja untuk dapat memahami objek yang menjadi secara ilmu yang bersangkutan.Menurut Sugiyono (2013:2) penelitian kualitatif adalah penelitian yang digunakan untuk meneliti pada kondisi obyek ilmiah dan memper oleh data, (sebagai lawannya adalah eksperimen) dimana peneliti adalah sebagai 
instrumen kunci, teknik pengumpulan data dilakukan secara wawancara antara tinga orang (gabungan), analisis data bersifat induktif, dan hasil penelitian kualitatif lebih menekankan makna daripada generalisasi.

Jenis penelitian menggunakan penelitian kualitatif,dengan mengambil lokasi penelitian di desaMojorejo adapun yang menjadi alasan peneliti mengambil lokasi penelitian ini yaitu dikarenakan peneliti ingin mengetahui sejauhmanainisiasikepala desa dalam pembangunan sumber daya manusia. Pada penelitian ini peneliti memperoleh data dari data primer dan skunder dengan teknik pengumpulan data melalui observasi, wawancara dan dokumentasi. Pengambilan sempel pada penelitian ini dilakukan dengan .penarikan sampel secara purporsive samplingdan yang menjadi instrumen penelitian yaitu peneliti sendiri. Pemeriksaan keabsahan data menggunakan triangulasi teknik yaitu melalui observasi, wawancara dan dokumentasi. Kemudian data yang terkumpul dianalisis dengan menggunakan teori Milles and Huberman (2013:2) yaitu dengan cara reduksi data, penyajian data dan penarikan kesimpulan.

\section{HASIL DAN PEMBAHASAN}

Desa Mojorejo mengenai pusat pertumbuhan telah memiliki pasar desa yang biasa disebut pasar kliwon, jadi setiap hari kliwon (bahasa jawa), namun nampaknya pasar terebut ternyata belum dimangfaatkan dengan baik oleh masyarakat Desa Mojorejo hal tersebut malah dimanfaatkan oleh penduduk luar desa, seingga yang berjualan di pasar tersebut mayoritas adalah orang yang berada dari luar desa. Masyarakat Desa Mojorejo sendiri yang harusnya memanfaatkan pasar tersebut untuk meningkatkan perekonomian namun disini masyarakat desa tungkulrejo menjadi pembeli bukan penjual. Hal tersebut sangat disayangkan adanya pusat pertumbuhan (pasar) ternyata belum mampu dimanfaatkan dengan baik oleh masyarakat desa.

Dalam hal ini pemerintah desa memberdayakan masyarakat untuk melakukan kegiatan dan untuk masyarakat juga. Dengan adanya pendanaan untuk melakukan kegiatan, maka dengan demikian masyarakat yang diberi amanah oleh pemerintah desa secara tidak langsung dapat mengembangkan kemampuanya dan juga dapat mengembangkan kemampuan masyarakat lain melalui kegiatan-kegiatanyang sudah direncanakan sebelumnya. desa mojorejo untuk melakukan pembangunan sumberdaya manusia melakukan kerja sama dengan Ibu-ibu PKK, Pemuda Karangtaruna dan juga Tokoh Utama masyarakat desa.

Adapun dalam pelaksananya terdapat tiga sifat dan jenis kegiatan yang mendorong pembangunan sumber daya manusia di desa mojorejo, sebagai berikut: Pertama kegiatan rutinseperti posyandu yang dilakukan setiap satu bulan sekali, Kedua pelatihan volly mulai dari usia dini setiap sore hari, Ketiga kegiatan perlombaan yang selalu rutindiadakan setiap saat peringatan hari kemerdekaan.

Desa Mojorejo terkenal dengan Desa Penghasil Bunga Mawar Potong yang dipasar kankeberbagai daerah bahkan sampai luar Pulau Jawa misalnya ke Kalimantan, Bali, Sumatra dan daerah-daerah lainnya. (1) Upaya pemerintah Desa dalam pemberdayaan sumber daya manusia yaitu: (a) Pemberdayaan sumber daya manusia, Kemajuan suatu bangsa dapat dilihat dari pertumbuhan dan pengembangan pendidikan masyarakatnya. Hal ini menunjukkan bahwa pendidikan merupakan kunci dasar dari suatu negara. Pendidikan sering di ibaratkan sebagai lambing kekuatan, kewibawaan dan kebesaran dari suatu bangsa dimanapun di dunia ini. Pendidikan pada hakikatnya merupakan suatu kebutuhan asasi manusia. Manusia terdidik akan memiliki daya cipta, rasa, karsa dan karya, dan pada saatnya manusia itu akan terjun kelapangan kerja dan dapat-dapatnya mencipta lapangan kerja. Upaya pemerintah Desa Mojorejo dalam pemberdayaan masyarakat disektor pendidikan yaitu melakukan pendekatan secara induvidu 
dan sosialisasiakan pentingya pendidikan dimasa yang akan dating bagi masyarakat desa Mojorejo. Upaya pemerintah desa Mojorejo pun bukan hanya memberikan pendekatan bagi masyarakatnya tetapi memberikan rekomendasi bagi masyarakatnya yang ingin melanjutkan studinya kejenjang yang akan berikutnya. (b) Pemberdayaan ekonomi masyarakat adalah usaha untuk menjadikan ekonomi yang kuat, besar, modern, dan berdaya saing tinggi dalam mekanisme pasar yang benar. Pemberdayaan ekonomi masyarakat, tidak cukup hanya dengan peningkatan produktivitas, memberikan kesempatan berusaha yang sama, dan hanya memberikan suntikan modal sebagai stimulant, tetapi harus dijamin adanya kerja sama dan kemitraan yang eratantara yang telah maju dengan yang masih lemah dan belum berkembang. Upaya pemerintah Desa Mojorejo dalam pemberdayaan masyarakat disektor ekonomi yaitu melakukan sosialisasi dan member bantuan langsung kepada masyarakat yang memiliki niat untuk membuka usaha kecil serta mempermudah dalam pengurusan surat untuk keperluan kebutuhan ekonomi masyarakat. (2) Faktor yang mempengaruhi upaya pemberdayaan sumber daya manusia yaitu: (a) Faktor pendukung, Pendidikan yang berkualitas adalah pendidikan yang mampu membina, pendidikan, dan mendewasakan manusia, maka pemberdayaan pendidikan masyarakat harus dilakukan melalui perubahan struktur. Respon positif dari masyarakat yang antusias dengan adanya sarana dan prasarana yang cukup baik, ini terbukti dengan keikut sertaan dan kehadiran masyarakat serta mendukung anak-anaknya untuk bersekolah. Adanya dukungan dari orang tua, masyarakat, pemerintah dan mitra lain, bekerja sama ikut mendukung anak-anak desa Mojorejo untuk sekolah. Perlu ditingkatkan kesadaran kepada anakanak/pelajar Mojorejo akan pentingnya pendidikan dimasa yang akan datang, serta orang tua berperan penting untuk mendukung anak-anak/pelajar. (b) Faktor penghambat, Pemberdayaan masyarakat dalam bidang ekonomi adalah penguatan bersama, dimana yang besar akan berkembang kalau ada yang kecil dan menengah, dan yang kecil akan berkembang kalau ada yang besar dan menengah. Oleh sebabitu, melalui kementrian dalam bidang permodalan, kementrian dalam proses produksi, kementriandalamdistribusi, masing-masing pihak akan diberdayakan. Untuk mengetahui faktor penghambat dan pendukung upaya pemerintah Desa Mojorejo dalam pemberdayaan masyarakat disektor ekonomi yaitu pemerintah desa berperan penting untuk meningkatkan dan member perhatian khusus kepada warga agar mendapatkan perekonomian yang merata dan mencukupi kehidupan sehari-hari.

\section{KESIMPULAN}

Inisiasi kepala desa dalam pembangunan sumber daya manusia guna memenuhi peluang kerja di Kota Batu disektor pendidikan yaitu pemerintah desa memberikan rekomendasi dan pendekatan secara individual kepada masyarakat yang kurang mampu dari tingkat TK sampai dengan Perguruan Tinggi, serta memberikan kesadaran kepada masyarakat akan pentingnya pendidikan dimasa akan datang dan dunia kerja.Inisiasi pemerintah membuka peluang kerja bagi masyarakat dan pemerintah menciptakan lapangan pekerjaanatau pemerintah melakukan perluasan kesempatan kerja di seluruh penjuru Indonesia, untuk memberikan pekerjaan kepada para pencari kerja sesuai dengan bakat, minat, dan kemampuan mereka. Faktor penghambat dalam upaya pemerintah desa disektor pendidikan dan ekonomi adalah tingkat kesadaran Masyarakat terhadap pendidikan apalagi masih belum maksimal dan kesedaran akan menempuh pendidikan tinggi. 
JISIP: Jurnal Ilmu Sosial dan Ilmu Politik

ISSN. 2442-6962

Vol. 9 No. 1 (2020)

\section{DAFTAR PUSTAKA}

Arikunto, S. (2002). Prosedur Penelitian Suatu Pendekatan Praktek, Cet. Ke-12. Jakarta. Rineka Cipta.

Darmawan, D. (2013). Metode penelitian kuantitatif. Bandung: Remaja Rosdakarya.

Effendy, O. U. (1997). Ilmu Komunikasi dalam Teori dan Praktek. Bandung: Remaja Rosdakarya.

Ibrahim, H. B. (1994). Rencana dan Estimate Real of cost. Belajar Teknik Sipil Indonesia.

Mardikanto, T. dan Sri Sutarni. T (2010). Redefinisi dan Revitalisasi Penyuluhan Pertaniaan. Sukoharjo-Solo: Prima Tresia Pressindo.

Mardikanto, totok, (2012). Pemberdayaan Masyarakat Dalam Prespektif Kebijakan Publik. Bandung: Alfabeta.

Mardikanto. (2012). Pemberdayaan Masyarakat Dalam Perspektif Kebijakan Publik. Bandung: Alfabeta jurnal.

Miles, M. B., \& Huberman, A. M. (1992). Analisis data kualitatif. diterjemahkan oleh Tjetjep Rohendi Rohidi. Jakarta: Universitas Indonesia Press

Moleong, L. J. (2006). Metode penelitian kualitatif edisi revisi. Bandung: Remaja Rosdakarya.

Rohman, A. (2018). Kepemimpinan Pelayanan Prima di Pedesaan. Reformasi: Jurnal Ilmiah Ilmu Sosial dan Ilmu Politik, 7(1).

Soetrisno, L. (1995). Menuju Partisipasi Masyarakat. Yogyakarta: Kanisius.

Sugiyono. 2009. Metode Penelitian Kuantitatif, Kualitatif, dan R\&D. Bandung: Alfabeta 